\title{
CHAPTER : MAJOR POLITICAL PARTIES IN ASSAM.
}

\author{
Dr. Subhash Talukdar. \\ SUBJECT TEACHER(P.SCI) \\ E-MAIL= $\underline{\text { subhashtalukdar68@gmail.com }}$
}

\begin{abstract}
Party system is the important factor in the working of representative form of Government. India is a democratic state. In the democratic state, political parties are said to be the life - blood of democracies. Modern democracies are indirect in character. They can function with the help of political parties. In the absence of political parties democracy cannot deliver the goods. Well organized political parties constitute the best form of democracy. India has the largest democracy in the world. It introduced universal adult franchise as the basis of voting right in the country. Now the voting age has been lowered down to 18 . Most of the Indian voters are not politically matured and they do not have the political education in the proper sense. Political parties in India are classified by the Election Commission of India. It was classified for the allocation of symbol. The Election Commission of India classified parties into three main heads: National parties, State parties and registered (unrecognized) parties.
\end{abstract}

\section{CHARACTERISTICS OF PARTY SYSTEM IN INDIA:}

India has a multi party system. It has some peculiar characteristics. The political parties are differing from other countries of the world. They are differing from western system. The characteristics or salient features of Indian party system may be analyzed as stated here under:

1. MULTIPLE PARTIES: In India there are a large number of political parties in India. Some are All Indian Political Parties and some are regional political parties.

2. COMMUNAL PARTIES: India is a secular State. Communal parties came in India. Though they could not captured power anywhere but they were popular in their own communities.

3. REGIONAL PARTIES: Some parties in India were regional in character. Their area is to particular regions. They are not based on the all-India.

4. LACK OF DISCIPLINE: Lack of discipline is another feature of party system in India. There must be discipline of every party. But there is lack of discipline in Indian political parties. As a result they revolt against their party.

5. ABSENCE OF IDEOLOGICAL ORIENTATION: All the political parties have no specific commitment to a particular ideology. The ideology of Marxism-Leninism constitutes the ideology of two Communist parties. Other parties have some aims. But it has no ideology. Most of the political parties are based on the Gandhism, liberalism and socialism.

6. RIGHTIST AND LEFTIST PARTIES: The rightist parties are that when it desires to maintain the status quo. Such parties do not like a revolution or a major change. The Lok Dal and BJP belong to this category. But a leftist party is one which desires basic and major changes in the social and economic set up the country. The CPI belongs to this category.

7. ROLE OF OPPOSITION: Another feature of party system in India is role of opposition party. There are opposition parties in everywhere. But they are not threat to the party in power. They cannot control the Government. But for success of democracy a strong opposition is essential.

8. DEFECTIVE ORGANISATION: Indian political parties are not properly organized. Some of them work in name only. They have no mass-contact and organizational network. They are active in the time of election but they in normal time they have no contact with them.

MAJOR POLITICAL PARTIES IN ASSAM: For the upcoming assembly polls, several new regional political parties formed in Assam. This election is likely to be held in the end of March and early April next year, 2021. These parties are Assam Jatiya Parishad (AJP), Anchalik Gana Morcha (AGM) and United Regional Party -Assam (URPA) formed by peasant leaders Akhil Gogoi's Krishak Mukti Sangram Samiti (KMSS).

\section{The Congress:}


The Indian National Congress Party, it is the oldest political Party of our country. It is like an umbrella organization. In 1969 INC was split. The progressive section, under Mrs. Gandhi leadership attacked the then collective leadership of the party under the president ship of Nijalingappa. Two organizations came into being as a result of this split - Congress (o) under Nijalingappas leadership and Congress (New) under Mrs. Gandhi's leadership. ${ }^{16}$ In 1977 Congress (o) merged with Janata. After the General Election of 1971, the INC came under the full control of Mrs. Gandhi. In 1977, it suffered heavily in the elections. Mrs. Gandhi came under sharp criticism. Mrs. Gandhi left the party and formed the Congress (I). The other Congress leaders became Congress (U) under the leadership of Dev Raj Urs. It became Congress (S) under Sharad Pawar. But all these Congress parties are ideologically same.

The Congress (I) was in power in the Centre and half of the states. It has two types of members, Primary and active. Primary Unit of the party was a village, town or an area. Local Unit is the Mandal Congress Committees, District Congress Committees, Sub - Divisional Congress Committees, Pradesh Congress Committees and the "All India Congress Committees". This organization was like a pyramid. The Central Committee has a Chairman. There is a working Committee. It has also a parliamentary Board.

Aims and objectives of the Congress: These are :-

1. The Indian National Congress stands for secularism, democracy, non-alignment and socialism.

2. The Congress has faith in the existence of justice - social, economic and political, Liberty of thought, expression, belief, faith and worship.

3. It also desire equality social, economic and political.

4. The Congress party wanted to abolition of untouchability and other social evils.

5. It wanted to give special facilities to the poor and backward classes of people.

6. The policies and programmed of the Congress party are based on four ideals - democracy, secularism, socialism and non-alignment.

7. The Congress party wanted to all round welfare of the common people. It gives the importance on employment and removal of poverty. Moreover it gives the importance on Scheduled Caste, Scheduled Tribes, other backward classes and poor people of the country.

\section{POLICIES AND PROGRAMMES OF THE CONGRESS:}

1. Modernization and development of agriculture.

2. Improving the lot of small and petty farmers.

3. Promotion of rural Banking.

4. Promotion of village industries.

5. Improving rural road transport system.

6. Insurance scheme for crops and cattle.

7. Rapid and balanced industrial development.

8. Increasing workers' participation in the management of factories.

9. Improving the condition of work for the women labour force.

10. To work for securing the interest of the weaker section of society.

11. Protection the interest of SC. ST, OBC and other weaker sections of society. 
12. To provide better health, family welfare and educational facilities for all the people.

13. To work for educational reforms and vocationalisation of education.

14. To follow the principles of Non-alignment, panchsheel, regional cooperation, peaceful nuclear policy etc.

The performance of INC is not so good in BTC area but in Assam, the Assembly election INC formed the Government since 2001 to 2015.

\section{Bharatiya Janata party:}

The Janata Party came in to being as a result of the merger of four parties - Bharatiya Jana Sangha, the Congress (O), Bharatiya Lok Dal and socialist party in 1977. The Bharatya Janata Party was formed after the split with the Janata Party. It was formed with the revival of Jan Sangha. The BJP has local committees, Mandal Committees, District Committees, the State Council and the State Executive. At the National level there are three organs of the party - national council, national executive and the plenary sessions. Three organs of the party have president and other members.

BJP has ideals like democracy, positive secularism, Gandhian socialism and value -based politics. It mentioned nationalism and national integration. It gives full protection to the minorities. BJP stands for establishment of economic democracy with equal opportunities for all. BJP support economic liberalism. It desires to activate some steps to be taken for stabilization of price and stands for making public sector productive and profitable. BJP stands to make drinking water available to all, reorganize panchayat in true spirit. It prevented bride burning and dowry death. It gives the importance on free and compulsory education up to $14^{\text {th }}$ years. Moreover it gives the importance on technical education, vocational education and adult education etc. To maintain international peace and security it supports the policy of non-alignment. It makes good relation with bordering countries.

IDEOLOGY OF BJP: The ideologies of BJP are as follows,

1. Clean administration and social justice.

2. Vibrant social order and international brotherhood.

3. Ram Rajya as the ideal.

4. Ram Mandir and Babri Majid issue.

5. Faith in secularism.

6. To remove Regional Imbalance.

7. Deletion of Article 370.

8. Development of Science and Technology.

9. Appointment of Law Commission and Human Rights Commission.

At present BJP support the popularity throughout India. This party came in power in some states and also power in the Center. From BJP Narendra Modi is the prime Minister of India from BJP, Sarbananda Sonowal is the Chief Minister of Assam. The first BJP, led alliance Ministry in Assam headed by Chief Minister Sarbananda Sonowal was sworn and presence of Prime Minister Narendra Modi. The performance of BJP is not good in BTC.

\section{Asom Gana parishad:}

AGP was formed in Oct. 1985 to fight the elections in Assam. In the history of Assam, it is for the first time, that a regional party has come to power according to the wishes of the majority of the people of Assam. In 1991, it contested the Assembly elections and captured majority of seats in the State legislative Assembly and formed the Government in Assam. 
The headquarters of AGP is in Guwahati. The Chief Minister of Assam is the president of the party. The party consists of vice - president, general Secretaries. The Chief Minister is the key man of the party. The AGP protect for all round development of the State. It developed the State industrially, economically and scientifically. This party stands to protect the interest of indigenous people. It wanted to implement the Assam Accord and remove corruption. The aims and objectives of this party are to work for the benefit of all.

\section{AIMS AND OBJECTIVES OF AGP:}

1. Establishment of a progressive society frees from exploitation, and based on economic development and social justice.

2. To work for the secularism, democracy, socialism, peace and social harmony.

3. To secure more rights for the State in real federal union.

4. Protection of forests and reserved areas.

5. Agricultural and industrial development.

6. To provide for full protection of the interests of local candidates in all matter of employment.

7. Promotion of the scientific temper.

8. Special protection for the SC, ST, OBC and weaker Section of the society.

After the formation of AGP, they participated in the Assembly election and won 64 seats out of 126 seats. In the general election of 1996, AGP came to the power with a clean majority. Recently, AGP make an alliance government with BJP. Atul Bora (AGP), Keshab Mahanta(AGP) are the cabinet Minister and sworn on 24 May, 2016.

\section{People's co-ordination for democratic right:}

Peoples Co-ordination for Democratic Right (PCDR) a political organization was formed with Suraj Musahary as co-ordination at a meeting held at Banargaon community hall in Kokrazhar.

It was formed jointly by All Bodo Student Union (ABSU), Bodo Peoples Progressive Front (BPPF), United Peoples Democratic Front (UDPF), and People Joint Action Committee for Bodoland Movement (PJACBM) and NDFB (P). Main aim and objectives of PCDR was peace and harmony among different communities. This organization formed on July 24, 2014 with Rwn Gwra Narzary, ABSU adviser as Chief Convener at Bodofa cultural complex in Kokrazhar. Last BTC election was held in 2015 and PCDR contested different Constituencies. PCDR won 6 seats in the BTC election 2015 out of 40 seats. Jiran Basu( PCDR) elected from Jomdur (ST) Constituency. Jyatindra Brahma (PCDR) elected from Dotma (ST) Constituency. Rwngwra Narzary (PCDR) elected from Kajalgaon (ST). Nirmal Kr. Brahma (PCDR) elected from Nichima (ST) Constituency. Guneswar Goyary (PCDR) elected from Subhaijhar (ST). Anil Kr. Basumatary (PCDR) elected from Kokilabari (ST).

\section{All India United Democratic Front (AIUDF) :}

The AIUDF is one of the Regional Political Party of Assam. It was formerly known as (AUDF), Assam United Democratic Front. It was formed in the eve of Assam Assembly Election 2006 and won 10 seats of State Assembly. Maulana Baduruddin Ajmal is the President and Hafiz Rashid Sowdhury is the General Secretary of AIUDF.

\section{Aims and objectives of AIUDF:}

The aims and objective of the AIUDF was as follows :

1. To work within the framework of the Constitution of India.

2. To work for the well - being of all exploited classes of people.

3. To stand behind the oppressed people and to render those all possible help to fight for their cause and suffering.

4. Permanent solution for infiltration problem. 
5. Permanent solution of insurgency problem.

6. Equal development for Adivasi, tea communities and other deprived communities.

7. To provide women empowerment and representation for women.

BODO PEOPLES' PROGRESSIVE FRONT:

The Bodo Peoples' Progressive Front (BPPF) is a regional political party in Assam. It was formed on $12^{\text {th }}$ April, 2005 for participation in the Bodoland Territorial Areas District (BTAD) elections. At that time Rabiram Narzary was the President of the BPPF and Hemendra Nath Brahma as the General Secretary of the BPPF. The head quarter of the BPPF is Kokrajhar. The major ambition of the BPPF is to create a new state called Bodoland for the Bodos. The party suffered a vertical spilt into BPPF $(\mathrm{H})$ with Hagrama Mohilary and BPPF $(\mathrm{R})$ with Rabiram Narzary. The preamble of BPPF is mentioned below -

The BPPF has its own Constitution and bye- laws based on which the party has been guided and doing its programme of actions including organizational structured. The Constitution begins with its preamble which bears the aims and objectives and goals, ideology, etc. As per the resolution No. 3 adopted in the political Convention held on $4^{\text {th }}$ and $5^{\text {th }}$ December, 2005 declared that we, the members of the Bodoland Peoples' Progressive Front( BPPF), adopted and gives ourselves this Constitution known as the Constitution of the Bodoland Peoples' Progressive Front shall bear true faith and allegiance to the Constitution of India as established by law and the principle of socialism, secularism and democracy as enshrined in the Indian Constitution. It would work for upholding the sovereignty, unity, and integrity of India. It emphasizes the international understanding on the important towards the development of Science and Technology and providing social justice to all, particularly to the children, women and disabled section of the society, development of education, promotion and safeguard of the cultural heritage and to promote around development of all sections of the people of Bodoland (BTAD) as well as Assam.

\section{OBJECTIVES OF BPPF:}

The objectives of the BPPF are -

i) To administer the Bodoland Territorial Area District and Assam as a through the principles of secularism, socialism and democracy;

ii) To work for the eradication of poverty and for the upliftmen of the downtrodden people living in the BTC area and Assam as a whole;

iii) To work for the Indian Nationalism with due respect to the identities of all sections of the society; and

iv) To strive for the alround development of women and children.

From the above discussion it is clear that the two main parties in Assam are the Bharatiya Janata party (BJP) which is the leading right - wing party and INC or Congree, which is the leading centre - left leaning party. Both of the political parties' active role in Assam. Now BJP is the ruling Government and INC is the opposition party in Assam.

\section{BIBLIOGRAPHY:}

\section{BOOKS:}

1. Agarwal, R.C. (1986), Indian Political System, S. Chand \& Company, New Delhi.

2. Ahmed, Kashem Ali (2010), The Muslims in Assam, EBH Publishers, Guwahati.

3. Awasthy, S. S. (1999), Indian Government and Politics, Anand Publications, New Delhi.

4. Ball, Alan R. (1983), Modern Government and Politics, The Macmillan Press, London.

5. Bannerjee, Kishal (1984), Regional Political Parties, B.P. Publishing Corporation, New Delhi. 
6. Ghai, U.R. (1992), Indian Political System,A Study in Government and Politics, New Academic Publishing, Jalandhar.

7. Hoque, N (2018), Role of AIUDF politics in Assam, An unpublished Ph.D Thesis AUS.

\section{NEWS PAPERS :}

\section{Assamese :}

1. Barman, Hemanta (ed.), The Danik Janambhumi, Janambhumi Press Pvt. Ltd. Guwahati (Assamese daily)

2. Deka, Kanak Sen (ed.) The Danik Agradoot, Agradoot Publishers Pvt. Ltd. Guwahati.

3. Bora, Nitya (ed.), The Asomiya Pratidin, Asomiya Pratidin Pvt. Ltd. Guwahati (Assamese daily).

4. Bargohain, Homen (ed.), The Amar Asom, G.L Publication, Guwahati (Assamese daily).

5. Hoque, Mozahadul (ed.), The Asomiya Khabar, Frontier Publication Pvt. Ltd. Guwahati (Assamese daily)

Hoque, N (2018), Role of AIUDF politics in Assam, An unpublished Ph.D Thesis AUS.

\section{English :}

1. Sarkar, Arup (ed.) The Telegraph, Media group Anand Publishers, Calcutta.

2. Baruah, Prafulla Govinda (ed.), The Assam Tribune, Assam Tribune Private Limited, Guwahati.

3. Bezboruah, Dhirendra Nath (ed.), The Sentinal, Sentinal Group, Guwahati.

4. Padmanabhan, Mukund (ed.), The Hindu, The Hindu Group, Chennai. 